〔日農医誌 61巻 6 号 925 930頁 2013. 3 3 ]

\title{
看護研究報告：
}

\section{その人らしく入院生活を送って頂くための関わり 難病患者に「センター方式シート」の一部を使用して—}

\author{
直井千恵子*
}

\begin{abstract}
当療養病床では寝たきり度が年々高くなっている。今回，頚椎後縦勒带骨化症，多系統 萎縮と 2 つの進行性難病を有し，日頃から数分毎の体位変換やポータブルトイレ移動，物

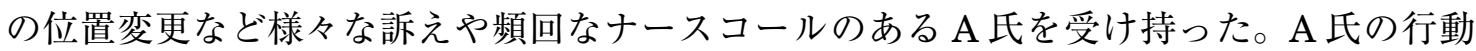
背景にあるものを明らかにし，ケアのヒントを見つけるため「認知症ケアマネージメント センター方式」の中の 1 シートである「私の姿と気持ちシート」を使用した。シートの使 用により運動障害の進行から思う様に身体が動かない事による心身の苦痛，自分の疾患を 理解して欲しいという思いが分かり，訴えの内容 1 つ 1 つを把握し援助を行なった。その 結果，以下のような成果が得られたので報告する。(1)患者は言動や表情が明るくなり気持 ちの変化が見られた，2スタッフは思い込みや押し付けの関わりを見直し先回りしたケア を心がける様になった，(3) 1 人の患者を知ろうとする姿勢が信頼関係を築き患者の望むケ アを援助に繋げる事が出来た。この経験により患者のなじみの生活や日常生活習慣を早期 に把握する事が，患者の望む環境や思いに添った療養生活を送って頂く事に繋がる事を学 んだ。
\end{abstract}

\section{(1)その人らしく (2)センター方式シート (3)難病}

\section{は じめに}

当院では平成19年より認知症ケアマネジメン 卜「センター方式」についての学習に取り組ん でいる。「センター方式シート」は認知症のた めのケアマネジメントシートであるが, 高齢者 ケア全般でこれを使用する事は有用であると言 われている。対応に行き詰まった事例に対しこ のシートを基に患者把握やケアの模索を行なっ ている。

今回，2つの進行性難病を有し日頃から頻回 なナースコールや細かい訴えが多い A 氏の行 動背景にあるものを明らかにし，ケアのヒント

\footnotetext{
* ₹506-0817＼cjkstart岐阜県高山市山口町1280 高山厚生病院看護部

(受付：2012年 8 月29日)
}

を得るためセンター方式シートの一部である 「私の姿と気持ちシート」を使用しケアを展開 した。患者の思いを知りそれに添ったケアを心 掛けた事でスタッフの患者に対する認識も変化 し患者の言動も変化した。また，その人らしく 入院生活を送って頂けるようになったので関り の実践を報告する。

「私の姿と気持ちシート」とは中央に患者を 描き，その周囲に 6 項目別に患者の気持ちを書 き入れ，患者のありのままの気持ちやその背景 を理解しようとするものである ${ }^{1)}$ (図 1 参照)。

\section{事 例 紹 介}

A 氏, 71歳, 男性, 平成18年澒椎後縦勒帯骨 化症と診断, 平成20年には多系統萎縮症と診 断。平成 21 年胃乃う造設, 徐々に下肢筋力低下 ありほぼべッド上生活となる。運動障害や四肢 


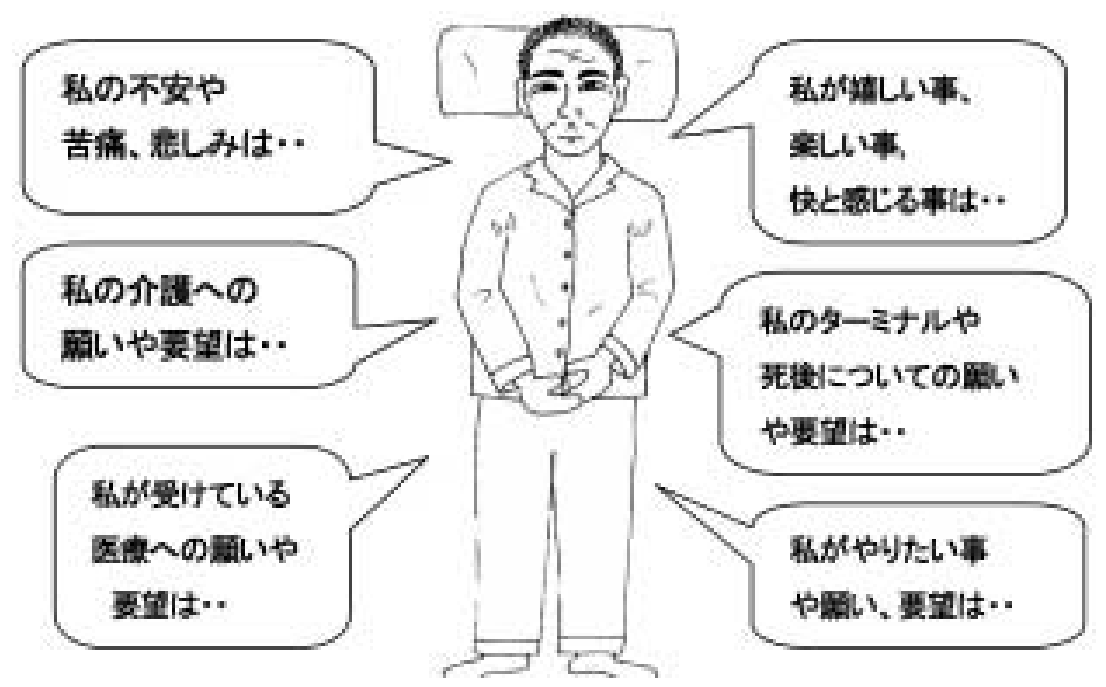

図 1. 私の姿と気持ちシート

の筋固縮，手足のしびれや痤攣の出現があり自 力での寝返りは出来ない。排泄はポータブルト イレを使用し介助者 2 名を要する。リハビリと 排泄行為以外はベッド上で過ごし全介助を必要 とする。意識は明暸ながら構音障害があり意志 の疎通は困難である。姉からの情報より性格は 几帳面で，仕事でも丁寧に正確に仕事をこなさ ないと気がすまないたちであった。

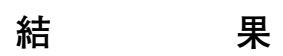

センター方式シート展開前の $\mathrm{A}$ 氏と看護の 状況

(1)ベッド上生活の A 氏はナースコールが頻 回で訴えの内容も細かく，1度訪室してもすぐ コールがあり 1 日のコール回数は平均 50 回程度 あった。同一体位で臥床していると下肢に疩れ や痛み，痤攣が出現するためほぼ 1 時間おきに コールが鳴り体位変換の要望があった。短い時 では30分から45分間隔でコールがあり，体位変 換を実施していた。

さらにベッド周囲の細かい物の位置，布団の 掛け方，ギャッジアップの高さ，体位に関する 要求が頻回にあった。定時に訪室して行なう眠 剤や下剂の投与時，経管栄養の開始時や終了 時，リハビリの車椅子乗車時などもその都度， 事前にコールがあった。ポータブルトイレへの 移乗は設置位置が $\mathrm{A}$ 氏の思い通りにならず，
何度も座り直す事もあった。このような状況 は，スタッフの身体にも負担がかかり $\mathrm{A} 氏 に$ 対し不満を感じるようになっていった。

(2)構音障害により発声は小さく，何度も繰り 返し聞き返す事が多く訴えや要望を理解するの に時間がかかった。スタッフとのやりとりの中 で聞き間違いもあり，スムーズに要望に添えな い事も多かった。

(3)リハビリでは上肢の運動，寝返りの訓練を されていた。運動機能が低下して行く中，日常 生活で訓練を生かした事は出来ないかと考え顔 拭きや歯磨きなど出来そうな事を進めてみたが 「出来ない」と拒否をされた。全てに全介助を 要求し，自分で何もやろうとされない $\mathrm{A} 氏$ 亿に 対し依存心が強いと感じるようになった。この ような事から A氏のケアに日々行き詰りを感 じるようになった。

そこで「私の姿と気持ちシート」を使用し， A 氏の思いを展開した（図 2 参照）。

シートから分かった事として，疾患により ベッド上生活をよぎなくされた心身の苦痛，他 人に依頼しないと生活できない悲しみと不安が ある事，自分の疾患を理解して欲しいという思 いが分かった。スタッフは日常生活で必要とさ れる援助を行なってはいたが，A 氏が几帳面な 性格で身の回りのすべてにおいてきちんとして いないと気がすまないという部分や，今まで当 


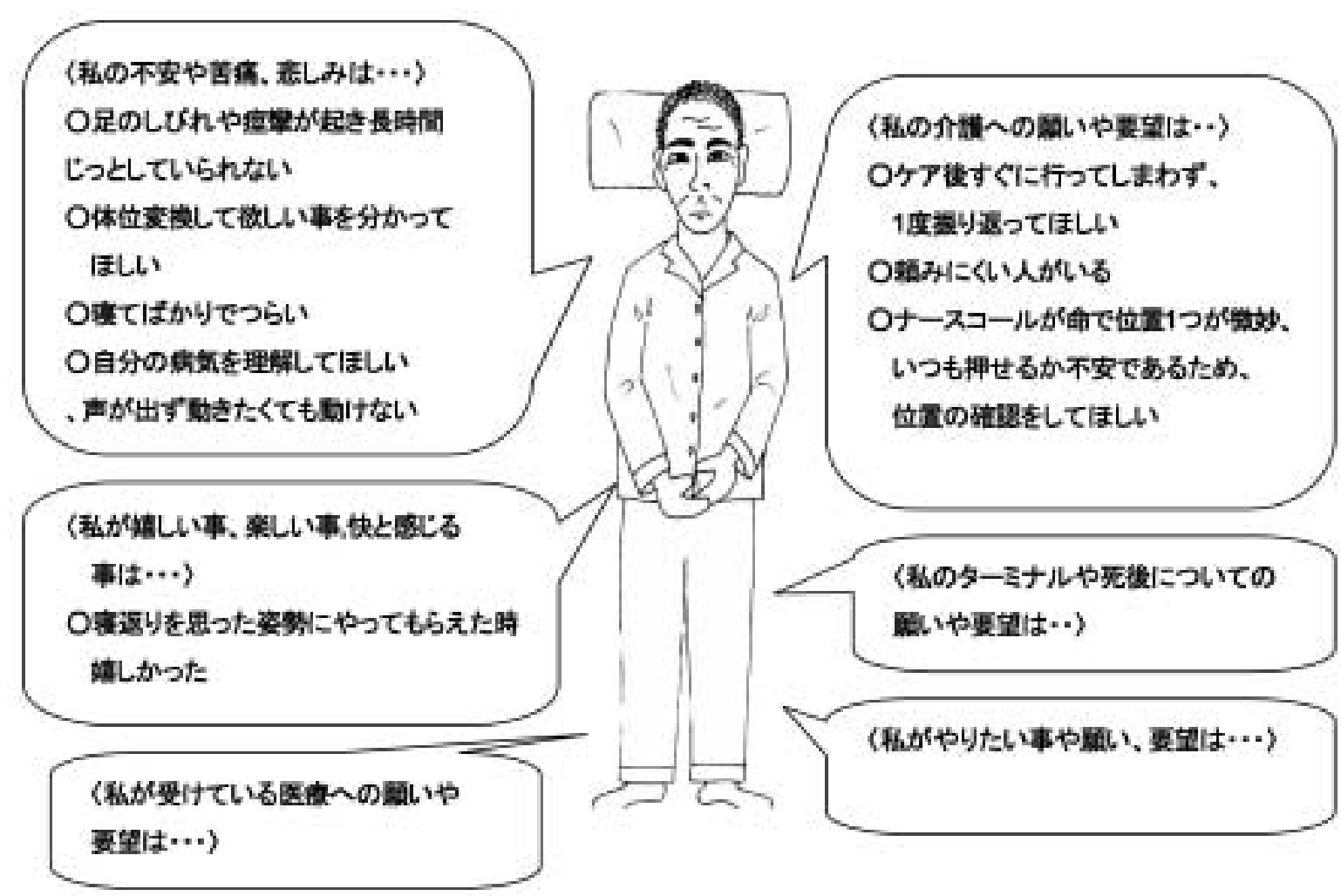

図 2. 関わり前の『私の姿と気持ちシート』

たり前にできていた事ができなくなった事の辛 さや悔しさを理解せず，A氏の捉え方を間違え ていると認識した。その場で体位やベッド周囲 の環境をしっかり整えてもらわないと安心，安 楽に過ごせないという思が分かり関わりを考え た。

(1)に対しコールで多い訴えを把握し先回りの ケアを実施した。ほぼ 1 時間おきの体位変換の 要望に対し時間を見計らいこちらから声をかけ 体位変換を実施した。また疾患の理解を深める ため看護師, 介護士共に疾患の学習会を行なっ た。長時間同一体位をとる事が下肢のしびれや 痤攣の出現に繋がり $\mathrm{A} 氏$ 氏って大変苦痛で ある事，その苦痛を取り除くために体位変換が 必要不可欠である事を理解した。また，A氏に とって安心できる療養環境を考え, ベッド周囲 の何処にどんな物が設置されているかを把握 し，A氏の希望する身近な環境を整えた。ベッ ド上での体位は A 氏が過ごし易い安楽な体位 を把握し，毎回希望の体位を整えるようにし た。排泄の訴えに対してもこちらから声をかけ
排泄要望を確認しながら介助を行なった。結 果，訴えやナースコールが減少した。

(2)に対し発声が小さく訴えが聞きとりにくい ため，話しを聞く環境を整えた。ラジオを聞い ている時はラジオを切り, 他の処置で話を聞け る時間がない時は処置が終わってから来る事を 伝え，終了後に時間をかけて訴えを傾聴した。 時間をかけて話を聴く姿勢で関わった事，日々 の関わりの中で訴えの内容も予測が出来るよう になった事で，聞き返す事が減少しケアもス ムーズに行なえるようになった。また，少しで も声が出るように訪室時は出来るだけ会話を多 く持つように関わった。

(3)に対し A 氏が何故「出来ない」と拒否さ れたかを考えてみた。シートの中でナースコー ルもやっとで押しているとの言葉より，上肢を 挙上する事は出来ても手先の細かい動きは困難 なのだと判断した。理学療法士からも「入院時 出来ていた事が徐々に出来なくなってきてい る。今後も少しずつとはいえ確実に症状が進行 して行くため, 現状をどれだけでも維持して行 


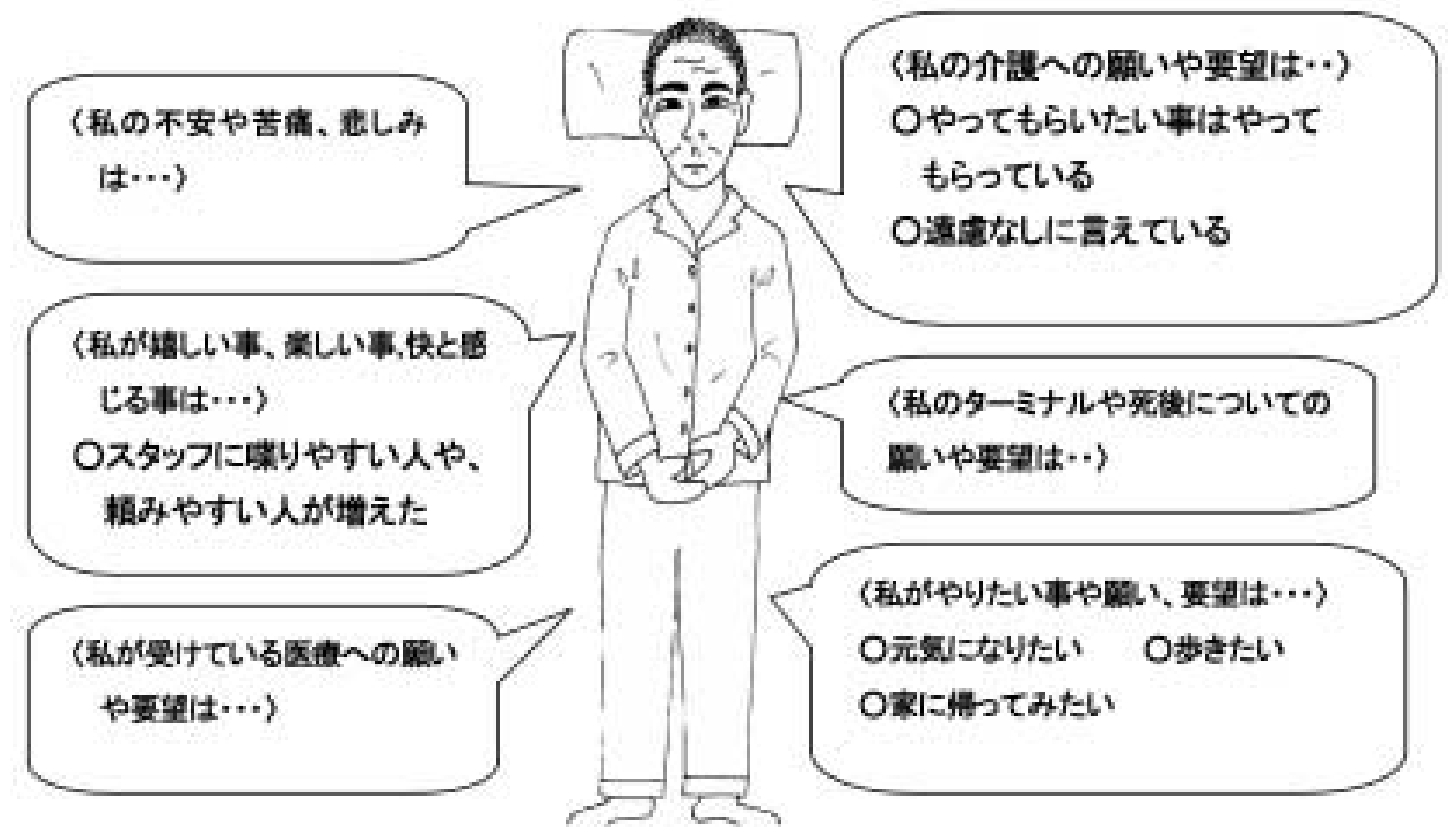

図 3. 関わり後の『私の姿と気持ちシート』

く事が大切」だと言われた。A 氏のためにと考 えた事であったが，結果的に $\mathrm{A}$ 氏の気持ちを 無視した押し付けの看護になってしまった。今 現在，出来ている事を維持して行く事が大切で あり，依存心が強いとの考えは改め，気持ち良 くケアを受けられる様にして行く事が大切であ ると考え関わるようになった。

関わり後，再度シートに思いを展開してみた (図 3 参照)。

関わり後のシートからは，少しずつ気持ちに 明るさが感じられ $\mathrm{A}$ 氏のスタッフに対する思 いにも変化が見られた。また前向きな要望も聞 かれるようにもなった。A 氏の変化として笑顔 が増え，時に呪談を言われるようになった。夜 勤帯でも頻回に体位変換の要望があったが， 3 〜 4 時間良眠され「安心して眠れる」と言われ るようになった。1日のコール回数は平均 50 回 から平均25回と減少した。

私達の変化として「私の姿と気持ちシート」 で思いを展開し A氏の思いを少しずつ知る事 ができた事で，A氏に出現している症状や状態 を疾患と照らし合わせて見直す事が出来た。ま た，思い込みや押し付けの看護をであった事に 気付き関わりを改める事ができた。さらに先回
りのケアを心掛けるようになり, 現在の A 氏 をそのまま受け入れる事の大切さに気付く事が できた。

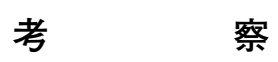

今回「私の姿と気持ちシート」を使用した $\mathrm{A}$ 氏の関わりより，患者の 1 つ 1 つの言動が大切 なサインであり，患者の気持ちを知る事に大き く活用する事が出来たと考える。シートを展開 する前では $\mathrm{A}$ 氏への関わりに行き詰まり感じ ていた。しかし，スタッフはナースコールに対 しベッドサイドに行く行動はとるものの, A 氏 が望む思いやケアに十分添う事なくベッドサイ ドを離れていた事に気が付き，コールの意味す るものが何なのかを考える機会となった。

小さな動きでさえ思う様に出来ない A氏の 希望がどのようであるかを理解し, ケアする病 棟スタッフ全員が統一したケアを提供するよう 関わった事で，A氏にとって安心出来る苦痛の 少ない療養生活に繋がったと考える。今まで自 分達の尺度で A 氏を困った患者と捉えていた が，気持ちを丁寧に把握し性格を含めて訴えを 解釈してみると, A 氏の訴えは決して特別では なく人間として当然と思われる要求であり，そ 
の事を理解し先回りのケアを提供した事が $\mathrm{A}$ 氏の言動の変化と不満と見られる要求の減少に 繋がったと考える。

センター方式シートでは，沢山の情報を持つ ばかりでなく肝心の患者の思いを知るため，患 者としっかり向き合い安心してその人らしく生 活していく為の課題を探る。「本人が伝えたい 事」「本人が求めている事」を寄り添う時間を 作り導き出していく ${ }^{2)}$ とるが，まずは相手を 知ろうとする姿勢が大切であると考える。今回 1 人の患者を知ろうとする姿勢は信頼関係にも 繋がり，相手の立場に立ち最期まで寄り添うケ アを行なう事が，患者の望むケアを導き出し関 わりに繋げる事が出来たと考える。

病棟の職種は看護師だけでなく介護職もいる ため，患者の病状の知識不足からケアの必要性 が十分理解できていなかった事も考えられる。 介護職を含めての学習会をもうけた事は, 疾患 を理解し症状と照らし合わせたケアの必要性を 共通理解する事に繋がったと考える。

2 つの進行性難病を発症し症状が徐々に進行 している中，A氏の今後への不安は計り知れな いものである。今後の A氏の身体的及び心理
的な状態に合わせ，その時必要な対応やケアを 考え病棟スタッフ全員が統一したケアを提供で きるように呼びかけていく必要がある。

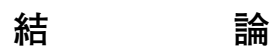

センター方式シート「私の姿と気持ちシー 卜」を使用する事で患者の思いや行動背景を知 る事が出来た。そして患者の日常生活習慣や望 む環境や思いを正しく把握する事が，その人ら しく入院生活を送って頂く事に繋がった。

\section{文献}

1 ）長谷川一夫，本間 昭，今井幸充，他．改訂 認 知症の人のためのケアマネジメント．センター方 式の使い方・活かし方，2009，203.

2 ）前掲書, 2009, 110-111.

3 ) 前掲書, 2009 .

4 ）中島紀恵子，井出 訓，植田 恵，他. 系統看護 学講座 専門20. 老年看護学, 2003.

5 ) 竹村信彦, 寺尾安生, 井上順子, 他. 系統看護学 講座 専門分野 II 成人看護学 7 脳・神経, 2009.

6 ）織田弘美，加藤光宝，佐藤嘉代子，他. 系統看護 学講座 専門分野 II 成人看護学 10 運動器, 2010. 


\title{
Steps to Enable Inpatients to Lead a Worthwhile Life \\ — Use of Center-formulated Work Sheet for Patients with Intractable Diseases
}

\begin{abstract}
Chieko NAOI*
The number of bedridden inpatients has increased year by year. Recently, I have been assigned to look after an inpatient (Mr. "A") with two progressively intractable diseases - ossification of the posterior longitudinal ligament (OPLL) and the multiple system atrophy (MSA). Usually, he would time and again phone the nursing station to demand a change in his posture or replace the bedpan. In order to clarify what lay behind Mr. A's behavior and grasp clues to his care, I referred to "My Posture and Feelings" in the booklet entitled the "Center for Management of Care for Dementia," and the referral enabled me to realize the pains caused by immobility of his body. The achievements I have made are:(1) That the in patient's expression has brightened and there have appeared changes in his feeling, (2) That the nursing staff has begun to clean up their cheap misunderstanding about his assertions and take legitimate action for him before his complaint, and (3) That the nurses' posture to try to know about the desire of inpatients has enabled them to come out with help of the kind the patients really wished to have. This experience of mine has enabled me to realize that the realization of the kind of daily lifestyle the patient wishes to have in an early phase, enabling him to lead the kind of life he wishes to have in hospital.
\end{abstract}

* Takayama Kousei Hospital, Gifu Prefectural Federation of Agricultural Cooperatives for Health and Welfare, Gifu, Japan 